\title{
Bird migration in the British Isles: its geographical and meteorological aspects
}

\section{W. Eagle Clarke F.L.S.}

To cite this article: W. Eagle Clarke F.L.S. (1896) Bird migration in the British Isles: its geographical and meteorological aspects , Scottish Geographical Magazine, 12:12, 616-626, DOI: $10.1080 / 00369229608732933$

To link to this article: http://dx.doi.org/10.1080/00369229608732933

曲 Published online: 27 Feb 2008.

Submit your article to this journal $₫$

Џ Article views: 7

Q View related articles 두 
Auchtow (more properly Achtubha) - Field or land producing thatch, i.e. sprits or rushes.

Auchtowmore-As above, with mor, great.

Beannach Aonghais-Blessing Angus. St. Angus is said to have introduced Christianity into the district. The tradition regarding the name of this place is that the worshippers from the north-east on arriving here, where they had the first distinct view of the place of worship, were wont to implore a blessing upon Angus. The phrase employed to invoke the blessing was, according to tradition, "Beannaich Aonghes san Aorainn." The site is still called the Aorainn by the old people.

Balquhidder-The town or district of the back-lying country (?).

Balbhaig-The still or silent-flowing.

Beinn Vorlich (Beinn mhoir luig)_-The hill of the great hollow.

Calair (Culair) -The stream coming in behind.

Glen Buckie-The glen of the bucks.

Glen Ogle (from Ogluidh)-The dismal or terrible glen, or high glen.

Loch Earn. Recent students of place-names give the derivations Loch-Ear-Abh-The loch of the easterly river, and of the Ernai (l).

Loch Lubnaig-The bent loch.

Loch Voil (Loch-a-Bheothuil)-The loch of the quick-running flood.

Loch Doine (Loch na Dubh Amhain)-The loch of the Black River.

Rinacraig (Rudha-na-Craige)-The promontory of the rock.

Ruskachan (Rusgachan or Riasgachan) from riasgach-The marshy land where coarse grass grows.

Strathire-The pronunciation of this word in Gaelic, which is straththeo-thir, makes its meaning more likely to be the "strath of the warm country," than what would seem the more obvious meaning (strath-fheoir) the "grassy strath."

Stuic-a-Chroin-Stuic, a lesser hill jutting out, as it were, from a greater; Stuc-a-chrodhain-hill of the cloven hoof.

Tom-nan Ainil (Aingeil)-The knoll of fires.

BIRD MIGRATION IN THE BRITISH ISLES: ITS.GEOGRAPHICAL AND METEOROLOGICAL ASPECTS. ${ }^{1}$

By W. Eagle Clarke, F.L.S.

(Natural History Department, Museum of Science and Art, Edinburgh.)

\section{Geographical.}

General.-In passing from their summer to their winter haunts, birds proceed from a northern to a southern clime, and vice vers $a$ in the spring. It does not at all follow, however, that these seasonal haunts are reached

1 From the Digest of Observations on the Migration of Birds at Lighthouses and Lightvessels, 1880-1887, presented to the British Association (Liverpool Meeting, 1896), by Wm. Eagle Clarke. 
by a simple movement from north to south, or the reverse. Each species or individual of migratory bird has its particular summer and winter resorts, and these do not necessarily lie in the same meridian-indeed this is often far from being the case. To attain these particular seasonal habitats, many of the voyagers must depart more or less considerably from a direct course. This is especially the case in Western Europe, where, owing to the south-western extension of the land-masses, and the consequent irregularity of the coastline, various more or less devious routes must be, and are, followed. The interposition of the British Islands between the north-western portion of the Continental Area on the one hand, and Iceland and Greenland on the other, is an important additional factor in this deviation.

The geographical distribution of birds during migration on the British and Irish coasts, and the routes traversed, naturally depend upon the nature of the particular movement.

The chief and most interesting movements, from the geographical standpoint, are the intermigrations between our Islands and Europe. There are, however, a number of movements between the various sections of the British and Irish areas, which are of considerable importance.

Internigration between Britain and Northern Continental Europe.Between Britain and Continental Europe travel a host of migrants, which are either birds of passage on, or winter visitors to, our shores. The former visit our eastern coastline in spring when journeying to their northern summer haunts lying to the north-east of Britain, and again in autumn when returning to their winter quarters to the south of our Islands. The winter visitors are chiefly individuals from the ranks of certain species of the birds of passage which winter in the British area and emigrate to the north-east in the spring.

In the autumn these numerous migrants cross the North Sea and arrive on the east shores of Britain at points between the Shetland Isles and the Humber, or the northern seaboard of Norfolk. All the movements do not necessarily cover this extensive stretch of coastline, but such is not infrequently the case. Indeed, as a rule, they are recorded from the greater part of the region indicated. It is possible to define the southern limit on the coast at which these birds strike Britain, with a considerable degree of precision. No section of the British coast is so well equipped with light-stations as that which lies between the north coast of Norfolk and Dungeness. In addition to an average number of lighthouses, there is a fleet of lightships off the coast, which are most favourably situated for recording the movements of birds crossing the North Sea to the English coast. These lightships have furnished the Committee with some of the most carefully kept records to be found among the returns, and it is a very significant fact that these great autumn immigratory movements are not observed at these south-eastern lighthouses and lightships. Evidence of a particularly important nature, in this connection, is also afforded by the records kept at the Outer Dowsing lightship, the most isolated of the stations in the North Sea, situated about thirty-eight miles E.S.E. of the mouth of the Humber. At this station these important movements are not observed-another significant fact, 
indicating unmistakably that these migrants pass to the northward or westward of this lightship.

The conclusion at which I have arrived, after a long and careful study of the records, is that these immigrants and emigrants from and to Northern Europe pass and repass between this portion of the Continent and Britain by crossing the North Sea in autumn in a south-westerly direction, and in spring in a north-easterly one, ${ }^{1}$ and that, while the limit to their flight in the north is the Shetland Islands, that on the south extends to the coast of Norfolk. ${ }^{2}$ During these movements the more southern portion of the east coast of England is reached after the arrival of the immigrants on the more northern portions.

It is to be remarked also, as bearing upon this important point, that all the species occur on migration in the Orkney and Shetland Islands, but not in the Færoes. ${ }^{3}$ And, further, all the British birds of passage to Northern Europe are either summer visitors to Scandinavia or are regular migrants along the western shores of that peninsula.

After arriving on our eastern shores, these immigrants from the north-some of them after resting for a while-move either down the east coast, en route for more southern winter quarters, or, if winter visitors, to their accustomed haunts in Britain and Ireland. A few occur as birds of passage on the west coast and in Ireland, which they reach by overland routes across Britain, and then pass southwards to their winter quarters. The west coasts, however, do not receive directly any immigrants from Continental Europe.

Intermigration between the South-east Coast of England and the Coast of Western Europe-" East and West Route."-This is one of the discoveries of the inquiry. It has been already shown that the more southern section of the east coast of England does not receive immigrants direct from Northern Europe. There is, however, a considerable amount of migration of a particular description, and on the part of certain species, observed at the lightships and lighthouses between the Kentish coast and the Wash. During the autumn, day after day, a stream of migrants, often of great volume, is observed off the coast, flowing chiefly from the south-east to the north-west at the more northerly stations, and from east to west at the southerly ones, across the southernmost waters of the North Sea. This will be hereafter mentioned as the "East and West Route." From the stations off the mouth of the Thames as a centre, the birds either sweep up the east coast, sometimes to and beyond the Tees (many proceeding inland as they go), or pass to the west along the southern shores of England. These important immigrations set in during the latter days of September, reach their maximum in October, and continue at intervals

1 The direction varies. It is probably more westerly (in autumn) or easterly (in spring) at the most northern British stations, and south-south-westerly (in autumn) or north-northeasterly (in spring) at the stations on the east coast of England.

2 The formation adopted by the migrants during passage would seem to be an extended line-perhaps a series of lines-whose right wing extends to the Northern Islands, and its left wing to the coast of Norfolk.

$3 \mathrm{~A}$ few species occur in the Feroes on migration, but these are also summer visitors to those islands and to Iceland. 
until November. They are chronicled with wonderful precision and regularity in the returns from the stations on the south-east coast of England. They are renewed during winter on occasions of exceptionally severe cold, but the birds then pass to the westward along our southern shores.

There are some remarkable features associated with these movements : (1) They are frequently observed for several or many consecutive days ; (2) they often occur when there is an almost entire absence of bird migration on other parts of our shores; (3) the movements appear to be entirely confined to the daytime, and are usually timed as from soon after daylight to 1 P.Mr., sometimes until 3 P.M.- - this being probably due to, and indicative of, the shortness of the passage; (4) the autumn migratory flocks are chiefly composed of Larks in vast numbers ; 'Black Crows' (Rooks) very many; Grey Crows, many ; also numerous Redbreasts, Goldcrests, Chaffinches, Greenfinches, Tree-Sparrows, Swallows, Starlings, and occasionally Woodcocks; and during the winter Larks, various Thrushes, and Lapwings; ${ }^{1}(5)$ and lastly, on certain occasions these immigrants, while passing northward along the English eastern seaboard, actually cross the movements of " coasting" emigrants proceeding southwards.

Whether this east to west stream is a branch of one that passes down the coast of Continental Europe, or whether it has its source in Central Europe, is a matter of conjecture. ${ }^{2}$

The conclusions relating to these continental migration-routes have been chiefly based upon the autumn data, because the information for that season is much more voluminous and complete. When, however, we come to examine the information relating to the spring movements, with a view to ascertaining how far they corroborate the conclusions so clearly indicated by the autumn chronicles, it is satisfactory to find decided evidence that the birds retrace their flight to the north and east along precisely the'same lines as those along which the autumnal southerly and westerly journeys were performed. Thus, in the spring, these birds depart from the same sections of our eastern seaboard as witnessed their arrival in the autumn.

Intermigration between Heligoland and Britain.-Much prominence has been given in some of the Annual Reports issued by the Committee, and in Herr Gätke's book, Die Vogelwarte Helgoland, to an intermigration between Heligoland and the east coast of England by a direct east-to-west autumn, and it is to be presumed west-to-east spring, movement. Herr Gätke most obligingly communicated the details of the bird-movements observed on Heligoland for four of the years (1883-1886) during which the inquiry was being prosecuted over the British area. These two sets of data have been carefully examined and compared, and it has been found that

1 It is probable that such species as the Golden Oriole, Hoopoe, etc., which occur annually during spring and autumn migration in southern and south-eastern England, and the Black Redstart as a winter visitor, are birds that proceed along this route to and from our Islands.

2 There are no essentially northern species recorded for this route, and the occurrence of the Rook so frequently and in such numbers is suggestive of a Central (Western) European source. 
the dates of the chief movements of the species common to Heligoland and Eastern Britain seldom if ever correspond, and do not bear out this theory; that particular species which are irregular as migrants in Britain, such as the Ortolan Bunting, and others, occur regularly, often indeed in "rushes," at the more favoured isle off the month of the Elbe; that other species, which are very rare on our British shores, occur in Heligoland as regular migrants and in considerable numbers, as Motacilla flava, Anthus Richardi, etc:; 'while species common to both islands occur in "flights like clouds," in "hundreds of thousands," "thousands upon thousands," in "marvellous numbers," "astonishing flights," and so on, at Heligoland, at periods when there is not a single observation for the same species on the English shores. A study of the phenomena of migration at the stations on the east and west sides of the North Sea compels the investigator to come to the conclusion that Heligoland and Britain draw their migratory hosts from different sources. The ordinary movements of any common migratory bird occur in each month of its seasonal flight-periods, and the mere coincidence of the species being observed simultaneously in ordinary numbers on both sides of the North Sea has no significance whatever. It is not impossible or improbable that birds may occasionally cross the German Ocean by an east-to-west flight in the latitude of Heligoland, but our data lead us to believe that such cases are the rare exception and not the rule.

Intermigration between Britain and Foroes, Iceland, and Greenland.The Færoes, Iceland, and Greenland are the summer home of several Palæarctic species which occur as birds of passage on the British coasts. The majority of these visit Iceland, and Greenland claims only two or three of them (Wheatear, White Wagtail, and Whimbrel). It is natural that these birds being strictly Old World species, our Islands should lie in the course of their migrations. It is quite possible that these migrants may pass along both the eastern and western coasts of Britain and the coasts of Ireland. . Here, at any rate, we have evidence that these birds are observed on passage on our western shores. It may be that some of the birds proceed also along our eastern seaboard, but this is a point difficult to determine. There is good evidence, however, that important movements of Redwings, Wheatears, and Whimbrels are observed on the western coast of Great Britain and the Irish coasts (both east and west as regards the passage of the Whimbrel), which are not observed elsewhere. Such a fact points to the independent nature of these west coast flights, and indicates that, in some instances at least, the western route alone is followed.

It is thus evident that, so far as concerns the movements of the birds of passage to and from their northern breeding haunts, the British east and west coast migratory movements are very distinct in their characters: The west coast does not receive immigrants direct from Europe, nor do these continental breeding species depart from its shores in the spring. Indeed, it is quite remarkable how rare, or comparatively rare, certain well-known east-coast species are on the western portion of our shores.

With the movements of the British migratory birds next to be considered it is quite different, for, with the exception of a few species whose 
summer haunts are much circumscribed in our Islands, the movements are not only common to both coasts, but the great emigratory flights are usually simultaneously observed on the east, west, and south coasts, and also on those of Ireland.

The west coast of Great Britain and the Irish coasts are thus only under much migration during the great autumn departure movements from our shores, and to a less extent during the return movements in spring.

Intermigration between Great Britain and Ireland and the South, etc.Having shortly described the migratory movements between the British Islands and Northern and Western Europe, undertaken by birds of passage and winter visitors to our Islands, the routes on our coasts along which the summer visitors ${ }^{1}$ travel to and from their breeding quarters in Great Britain and Ireland now demand attention in their geographical aspect. It will be convenient also to refer to the routes between the different portions of the British area under this division.

The autumn or emigratory movements will be described-but it is necessary to remark that the data clearly indicate that the spring migratory movements along our western shores are simply return movements, on the part of the same species, along the same lines of flight as those laid down for the autumn.

The movements of these groups of migrants will be treated of under the various sections of our coasts. The first movement on the part of all emigrants among British birds is to the coast, which is reached in some cases, no doubt, by particular inland routes;

East Coast of Great Britain.-The emigratory movements on the east coast are very simple in their geographical aspect. When the coast is reached, the emigrants follow the coastline southward, gathering strength as they go, and finally quit our shores at various points on the south coast of England.

It is during such autumnal movements that the more southern coastline of Eastern England, and its off-shore fleet of lightships, record night migration. The ranks of the British emigrants are, as we have said, recruited as they fly onward, and if a great movement should be in progress, the causing-influence will affect also many birds of passage which may be sojourning on our shores. Two wings of the migratory army thus combine, and a great "rush" to the south is the result.

West Coast of Great Britain.-The emigratory movements which pass down the west coast are far from being so simple in their geographical details as those observed on the east.

That such should be the case is not surprising. Here we have Ireland, the Isle of Man, the Hebrides, and an extremely irregular coastline exercising their varied influences. In addition, there are intermigrations between these off-lying isles and the mainland, and often movements of an independent nature in some portion of the western area.

The general route followed by these departing birds has its northwestern source in the Outer Hebrides, and after leaving Barra Head it

1 Those birds which are only partially migratory are included in this category. 
joins an important stream from the Inner Hebrides at Skerryvore. The course then followed is via Dhuheartach, Islay, the Wigtonshire coast, the Isle of Man, Anglesey, and the South Bishop (off Pembrokeshire). Finally, the south-western coast of England is reached (possibly in part by an overland route across Devonshire and Cornwall) between the Scilly Islands and Start Point.

In its course southward considerable tributaries, so to speak, are received at Cantire, Arran, the Ayrshire and Wigtonshire coasts, and the Solway, of birds passing down the west coast of Scotland. At the Bristol Channel emigrants are received from western England and Wales, and often also important contributions are added from the south-eastern coast of Ireland.

In connection with these movements there are several more or less important features to note. (1) The English shores of the Irish Sea, -i.e. the coasts of Cumberland and Lancashire-lie off the main line of these movements; (2) the north coast of Ireland, which seems to lie right in the course of the birds, and which would naturally be expected to come in for a considerable share of such movements, appears to be only occasionally affected by them; (3) the Irish contributory movements, when they occur, are chiefly, nay almost entirely, observed on the southern, and especially the south-eastern coasts; (4) the south-western coast of England and Wales-i.e. from the mouth of the Bristol Channel to the Land's End and the Scilly Isles-appears to be especially affected when there are considerable movements on the southern and south-eastern coasts of Ireland, implying that there is much intermigration between these particular portions of the English and Irish coasts. Sometimes, however, these emigrations from Ireland only affect the south-west coast of England from the Bishop's Rock (off Scilly) to Start Point.

Irish Coasts.-The Irish chronicles have been most excellently and carefully kept, and the returns of specimens killed against the lanterns at the stations have been larger and more valuable than those furnished from the coasts of Great Britain.

The coasts of Ireland do not constitute in themselves a main highway for birds, though they participate, along with the western shores of Great Britain, in certain movements to and from the far north on the part of the section of the birds of passage already alluded to. Indeed, the majority of the migrants observed on the shores of the sister isle are probably the migratory members of her own avifauna.

The movements of departing birds during the autumn at the southern and south-eastern stations have already been mentioned, and when migration is going on at this part of the coast there is often recorded an emigratory movement along the western coast from Slyne Head southwards, which probably forms a contributory stream to the general movement to the south. These Irish emigrations, as a rule, occur simultaneously with similar movements passing down the western coast of Great Britain, and the two streams meet and unite at points between the Bristol Channel and the Scilly Isles. Some of the Irish autumnal flights, however, are quite independent of these general movements.

There is much evidence to show that not only do the autumnal 
emigrants depart from the south-east coast of Ireland en route for more southern winter-quarters, but also, strange to say, that many birds (e.g. Thrushes, Redwings, Blackbirds, Chaffinches, Greenfinches, Linnets, Starlings, Larks) almost simultaneously enter that country by this very same section of her shores, in order to winter within her limits. These immigrants are often observed arriving from the south-east in great numbers for several days in succession. The English west-coast observations also bear evidence that such movements proceed across St. George's Channel in a north-westerly direction. These cross-channel flights are usually observed during the daytime, but sometimes the arrival of certain of these birds on the Irish coast takes place during the night.

According to the records it is only occasionally, as already stated, that the southerly autumnal movements from Western Scotland are observed at the northern Irish stations. Now and then, however, there is evidence that a considerable number of birds do arrive on, or skirt, the north coast of Ireland during the more pronounced west-coast emigratory flights.

Independently of, and in addition to, these main Irish migratory movements, Thrushes, Larks, and Starlings occur in October and November on the northern coasts of Ireland from Tory Island to the Maidens as immigrants from Scotland. These are to be correlated with movements of the same species observed at the Rhinns of Islay and the Wigton coast. Larks, too, are often recorded for this route during the daytime.

There are also autumnal movements between Ireland and England and Wales by an east to west flight across the Irish Sea, on the part of Starlings, Chaffinches, Greenfinches, Larks, and sometimes of various species of Thrushes. Anglesey is the chief Welsh point, and Rockabill (off the north coast of $\mathrm{Co}$. Dublin) the main Irish station at which these departures and arrivals are observed.

'The migratory movements observed on the west coast of Ireland are neither many nor important, and consist almost entirely of movements on the part of emigratory Irish birds. There are, however, remarkable immigrations from home sources witnessed on the west coast and its offlying islets during great cold and snow.

South Coast of England.-It is much to be regretted that observations relating to the migrations of birds on the southern coast of England as a whole were not obtained by the Committee. The data bearing upon this important English coastline are from a few stations on the south-eastern and south-western portions only.

This information points to (1) a considerable amount of migration taking place between these portions of the coastline and South-western Europe; and (2) important movements passing along the entire coastline from east to west in autumn and probably vice versâ in spring.

The south coast is naturally the great scene of the arrival and departure of migratory birds of all descriptions, but the movements along shore are, perhaps, in some of their aspects, more interesting. Regarding these last, much remains to be ascertained concerning their precise nature and the destination of some of the birds travelling along this route.

In the autumn this coasting stream of birds has its source chiefly in 
the immigratory movements from the Continent across the southern waters of the North Sea by the East and West Route, of which it is but a continuation. It is possible, also, that British emigrants, after passing down the east coast of England, may turn to the westward and skirt the south coast, but this is not shown with certainty.

The continental immigrants strike the Kentish shore, and, as has been already stated, some pass to the north along the east coast of England, while others pursue a westerly course along our shores of the Channel. The stations on the south-western coast again record these migrants, and the probable destination of many, perhaps most of them, is Ireland, on whose south-eastern shores the birds are chronicled, almost simultaneously, as arriving in great numbers from the south-east.

It is possible, however, that some of these birds-the Skylark especially-may reach a much more remarkable destination, for one branch of the stream sweeps northwards, being observed at the mouth of the Bristol Channel, at Anglesey, and at the Isle of Man stations, proceeding to the west and north-west, probably to Northern Ireland; while on the Wigtonshire coast and at the rocks of Dhuheartach and Skerryvore these birds are noted as moving in the direction of the Outer Hebrides.

The great autumnal movements from east to west along the south coast of England are renewed in winter, when that season is characterised by periods of unusual cold. At such times it is possible that this western stream is composed in part of native emigrants which have passed down our eastern coasts, as well as of birds of continental origin.

Channel Islands.-Records from the Hanois lighthouse, situated some two miles off the west coast of Guernsey, were furnished for each of the years of the inquiry, and afford some useful information. These, when compared with the English and Irish chronicles, show that on nearly every occasion on which considerable migration was observed at this station in the autumn, there was also much emigration going on practically simultaneously on the south-west coast of England. It is necessary, however, to state that a number of important movements on the south-west coast of England do not appear in the records for Hanois, indicating, perhaps, that many movements to the south in autumn, and to the north in spring, pass to the westward of this station. In the spring, Swallows are observed passing to both the north-east and north-west in great numbers during April and May, and a number of other summer birds are recorded on passage.

\section{Meteorological. ${ }^{1}$}

When studying bird migration in connection with meteorological conditions, it is only necessary to consider the weather peculiarities prevailing in the area where the movement has its origin. The weather prevailing upon the shores reached after an extended flight does not affect the movement. An extensive series of comparisons instituted

3 The following is only a brief abstract of the section in Mr. Eagle Clarke's report. 
between the records of migration and the Daily Weather Reports of the Meteorological Office, shows an intimate connection between weather and bird migrations.

During the spells of genial weather that occur in both the spring and autumn periods of migration, the movements are of an even and continuous nature. If the weather at such times becomes slightly unsettled, it is a matter of indifference to the migrants; but if it becomes more markedly variable, their movements are somewhat quickened.

Certain weather conditions, however, have a very decided influence in either hindering or promoting migration. Unfavourable conditions of a pronounced nature may render migration impossible, while, on the other hand, favourable weather following unfavourable periods may tempt birds to start on their way. A decided fall of temperature warns them to move southwards, and such cold spells are characteristic of anticyclonic periods when the weather is calm and highly favourable for a prolonged flight. The most important factor is temperature, and it regulates migration, other meteorological conditions being favourable.

From the end of September to early in November the autumn migrations into our islands from the north-east are sufficiently pronounced to be associated with weather changes. In ordinary seasons the period named is characterised by a series of great immigratory movements simultaneously performed not only by many species, but also by a vast number of individuals. It has been ascertained that all these great movements are due to the prevalence of weather conditions favourable for emigration in north-western Europe. These conditions are the result of the following type of pressure distribution-namely, the presence of a large and well-defined anti-cyclone over the Scandinavian Peninsula, with gentle gradients extending in a south-westerly direction over the North Sea. On the other hand, cyclonic conditions prevail to the westward of the British area, with a low pressure centre off the west coast of Ireland, or, occasionally, farther south. Consequently the weather is clear and cold, with light variable winds, over Norway and Sweden; while in Britain the sky is overcast, and moderate to strong easterly winds are experienced. Previously to this period cyclonic conditions usually prevail in Scandinavia, which check migration and at the same time warn the birds that it is time to depart. The fall of temperature on the formation of the anticyclone is another incentive, and it is not surprising that there is a rush southwards as soon as the weather becomes favourable.

The gentle pressure gradients do not always extend entirely across the North Sea, and the emigrants may fall in with bad weather before they reach our shores. If the western cyclonic system is too close to Britain, or if the depression is exceptionally deep, strong winds prevail on the eastern coasts, and the birds perform the latter part of their - journey under trying conditions. The autumnal immigration by the "East and West Route" are subject to much the same influences. Of course, in addition to the favourable and unfavourable conditions described above, there are intermediate phases, whose influences ar easily determined by a study of the two sets of phenomena.

voL. XIr. 
The great spring emigratory flights, and most of the lesser ones, are undertaken under precisely the same type of pressure distribution as is so favourable to the autumn immigrations, namely, high pressure to the north-east of our islands over Norway and Sweden, with gentle gradients to the south-west. As in the autumn, the favourable periods usually follow spells of weather decidedly unpropitious for bird migration.

The importance of winds in connection with bird migration has been much over-estimated. The direction of the wind seems to be a matter of indifference; but its force may arrest migration or carry birds out of their course. Birds do not emigrate when the wind is exceptionally high, but they pay no attention to the direction from which it blows. It is true that particular winds (easterly) almost invariably prevail during the great movements, and hitherto they have been considered as direct incentives to migration. Such is not the case, and it may be at once stated that these supposed favourable breezes are simply another direct result of the pressure distribution favourable to the movements. As far as direction is concerned, westerly winds would be equally favourable to the emigration, but they are produced by cyclonic disturbances to the north or east of the British Isles, that is, over the areas from which our autumn immigrants come.

Gales have already been alluded to as arresting migration or rendering it impossible. They also sometimes sweep certain marine species out of their course, and hence these birds sometimes appear on our coasts in exceptional numbers. In foggy weather, characteristic of high pressure systems, birds are frequently killed in great numbers against the lanterns of the light-stations, and often lose their way.

\section{THE COUNTRY OF THE YAKUTS.}

IT is singular that a people inhabiting a country where the climate is so severe as in the north of Siberia, and even the necessaries of life are in some seasons difficult to obtain, should preserve their racial characteristics and habits in the face of invaders of far superior culture. This is, however, the case with the Yakuts; their nationality is of such vitality that, far from showing any sign of disappearing before the advance of Russian civilisation, it impresses its stamp on the invader, and the Russian immigrants become "Yakutised." The Yakuts have, therefore, naturally attracted the attention of Russian ethnologists, and much has been written on them and their country in the Russian language. One of the most complete accounts of this people has lately appeared in a large work ${ }^{1}$-or rather the first volume-written by M. V. L. Seroshevski, who frequently visited the country between 1880 and 1893. Before discussing the Yakuts he describes the country they inhabit, both from his own observations and from those of former travellers.

I Yakuty. Opyt etnograficheskavo Izsliedoraniya. V. L. Seroshevskavo. Tom. I. St. Petersburg, 1896. 